\title{
Termination of the contract: Principles of European Contract Law and the Law on Obligations of the Republic of Macedonia
}

\author{
Faton Shabani \\ PhD Candidate, State University of Tetova \\ Email: faton.shabani@unite.edu.mk
}

\section{Doi:10.5901/mjss.2015.v6n4p307}

\begin{abstract}
The purpose of this paper is to present a short introduction to the remedy of termination provided by the Principles of European Contract Law (hereafter PECL) and the Law on Obligations of the Republic of Macedonia (hereafter Law on Obligations). Both instruments indicate that have prescribed the possibility of terminating the contract for non-performance. The author begins with an overview over the definition of the remedy of termination as ultima ratio remedy. Following, the review focuses on the PECL, considering cases of fundamental non-performance and additional period of time; and on the Law on Obligations, considering cases of termination: when performing within the specified period of time is a basic term of a contract, and when performing within the specified period of time is not a basic term of contract. The paper concludes with a comparative assessment of the remedy contained within two aforementioned regulations highlighting the similarities and differences between them regarding to termination.
\end{abstract}

Keywords: termination, PECL, Law on Obligations.

\section{Introduction}

In serious cases of non-performance by the contracting parties, the termination of the contract is unilateral right to the aggrieved party to terminate the contract with its simple declaration. No other remedy that recognizes the theory and practice of the contract for the sale of goods, such as claim for performance, price reduction, cure by non-performing party or right to damages - has the same incisive effect. However, the applicability of the right to termination that today is found in international practice of contract law has not long history. Roman law had giving importance to the will of parties' compliance as a key element for the formulation and conclusion of the contract, by the old maxim, pacta sunt servanda: the contract must be maintained. Despite the generally accepted position that the contract be fulfilled, it should always keep in mind the possibility of not fulfilling by one or both parties (Галев, Дабовиќ-Анастасовска, 2009). Termination of the contract as presented in this paper, is a reaction to a disturbance in the performance of the contract. Other terms that are frequently used in the legal world include 'rescission', 'cancellation', and 'avoidance' (Schwenzer, Hachem, Kee, 2012). In particular, it must be distinguished from the rescission, since the rescission of the contract operates to negative retroactively the validity of the contract.

Contemporary laws, today contain general rule that when the contract is bilateral or so called a two-sided contract, one party fail to perform a causal promise, the other party may, in accordance with the enforceable law, terminate the contract unilaterally through the expression of the will. However, a thorough comparative analysis reveals that under most legal systems it is decisive whether the breach reaches certain level of seriousness (Schwenzer, 2010). The basic question today is not whether there is a right to terminate, but when it will be available to the aggrieved party. In particular, the aggrieved party may only terminate the contract in case when the other party's breach amounts to a fundamental breach of contract. International legal provisions give effect to this policy strictly limited to situations in which the parties have the right to terminate the contract. The purpose of putting of the institute of fundamental breach is to minimize the exercise the most drastic remedy only to situations where the breach was really serious. Being considered as an ultima ratio remedy, the right to terminate the contract will intervene when the other remedies (the right to require performance, claims for damages or price reduction) are insufficient (Schlechtriem, Schwenzer, 2005). This approach was picked up at the European level by the PECL, as well as national legislators, although with certain changes, as in case of the Law of the Republic of Macedonia.

There are two main rules for termination of the contract under PECL: if the other party's non-performance is fundamental, and after expiry of additional period of time; while, the Law on Obligations makes able the right to terminate 
in cases: when performing within the specified period of time is a basic term of a contract, and when performing within the specified period of time is not a basic term of a contract. On the other hand, PECL and the Law on Obligations, contain provisions about some other forms of termination, such as: termination for anticipatory breach, termination in the case of instalment contracts, or termination without fixing additional period of time. However, due to contractual practice these forms of termination are rarely encountered, which has prompted the author to focus the analysis only on the aforementioned basic cases of termination.

\section{Termination under the PECL}

\subsection{Introductory considerations}

The PECL is a set of rules prepared by a commission under the chairmanship of Ole Lando. Yet, as the name indicates, the focus is on the Europe and more specifically on the members of the European Union. Drafted by a group of the most famous names of the theory and practice of contract law at the time, PECL considered to be presented as "set of general rules which are designed to provide maximum flexibility and thus accommodate future development in legal thinking in the field of contract law" (Lando, Beale, 2000). Basic rules for termination of the contract are set out in Article 9:301: "(1) A party may terminate the contract if the other party's non-performance is fundamental; (2) In the case of delay the aggrieved party may also terminate the contract under Article 8:106(3)". From this, it can be seen that this article regulates the remedy of termination in general terms, addressing the concretization of the principles on which rely this remedy on the other articles of PECL.

There are two prerequisites that need to be met for the party to be able to terminate the contract: (1) the breach is fundamental; and (2) where the breach is not fundamental (usually in the case of delay in delivery of goods) the aggrieved party fixed an additional period of time, but the party in breach didn't perform within that period. Article 9:301(1) accepts the doctrine of fundamental breach as the first rule for the availability of termination. This doctrine limits the ability of the aggrieved party to terminate the contract to cases where the breach is so serious that it amounts to a fundamental breach. The second rule is the so-called Nachfrist, which requires the aggrieved party to determine an additional period of time for performance, and if this addition period of time has expired without success, i.e. without the party in breach have performed properly, the party which fixed this period of time can terminate the contract. This means that the mere breach as such does not yet entitle the aggrieved party to terminate the contract, but it has the chance to 'transform' the nonperforming party's breach in a worthy one of being the reason for contract's termination. In addition, given that in principle is not allowed "ipso facto" termination, the PECL obliges the party to give a notice to the other party.

\subsection{Termination for fundamental non-performance}

The first requirement for a right to terminate under Article 9:301(1) is that there was a fundamental non-performance. Non-performance is defined as an act that "denotes any failure to perform an obligation under the contract, whether or not excused, and includes delayed performance, defective performance and failure to co-operate in order to give full effect to the contract" (Article 1:301(4) of the PECL). In addition, it is not important whether the non-performance was excused, as is the case of force majeure. However, the non-performance must be fundamental one. The PECL maintains that nonperformance of an obligation is fundamental if:

(a) strict compliance with the obligation is of the essence of the contract;

(b) the non-performance substantially deprives the aggrieved party of what it was entitled to expect under the contract, unless the other party did not foresee and could not reasonably have foreseen that result;

(c) the non-performance is intentional and gives the aggrieved party reason to believe that it cannot rely on the other party's future performance (Article 8:103 of PECL).

The agreement between the parties concerning the subject of the contract is the central element, while any noncompliance of this agreement affects the essence of the contract at the same time gives the aggrieved party the right to be discharged from its obligations under the contract. Thus, the contract may provide in terms that in the event of any breach by a party the other party may terminate the contract (Lando, Beale, 2000). Insofar the importance of the interest which the contract creates for the promise is crucial. It is the contract itself that not only creates obligations but also defines their respective importance for the parties (Schwenzer, 2010). Secondly, it is clear that the standard for fundamentality is high: it must concern the essential content of the contract, the goods, or the payment of the price concerned, and it must lead to serious consequences to the economic goal pursued by the parties (Kröll, Mistelis \& Viscasillas, 2011). Where the effect of non-performance is substantially to deprive the aggrieved party of the benefit of its 
bargain, so that it loses its interest in performing the contract, then in general the non-performance is fundamental (Lando, Beale, 2000). The breach shall not be treated as fundamental if the party in breach did not foresee and a reasonable person of the same kind in the same circumstances would not have foreseen such a result. Thirdly, the nonperformance is intentional and gives the aggrieved party reason to believe that it cannot rely on the other party's future performance, especially when dealing with instalment contracts.

\subsection{Termination after expiry of additional period of time}

In any case of non-performance the aggrieved party may fix an additional period of time for performance. This additional period of time in the contract law is familiar with the notion of German language "Nachfrist", from where it has its origin. Its main purpose is providing additional period of time for performance to remove any doubt of the aggrieved party when it is not certain that the breach is sufficiently fundamental as to authorize it to declare termination of the contract. However, the PECL, in contrast to German law, establishing the institute of additional period of time as an opportunity of aggrieved party, not as duty. Fixing an additional period of time means that the aggrieved party still wants the existence and fulfillment of the contract by providing the other party a chance to fulfill the contract nonetheless. If the non-performing party does not perform within the additional period, the aggrieved party may terminate the contract. The right to terminate the contract derives from Article 9:301(2) "In case of delay the aggrieved party may also terminate the contract under Article 8:106(3)." Further, Article 8:106(3) concretizes the termination in case of additional period of time "If in case of delay in performance which is not fundamental the aggrieved party has given a notice fixing an additional period of time of reasonable length, it may terminate the contract at the end of the period of notice."

The purpose of the provision is to remove a double uncertainty. First, it removes the uncertainty about whether and when the party will fulfill its obligations. Second, the provision removes the uncertainty about whether non-performance amounts to a fundamental non-performance (Bianca, Bonell, 1987). In other words, the creditor by fixing an additional period of time 'upgrades' minor non-performances so as to justify termination of the contract.

\section{Termination under the Law on Obligations}

\subsection{Introductory considerations}

In two-sided contracts where one party fail to perform any of its obligation, the other party, unless is otherwise expressly provided, may require performance of obligations or under conditions provided in the following articles, terminate the contract with simple declaration, if the termination of the contract not occurs according to the law, and in any case the party retains the right to claim damages (Article 113 of the Law on Obligations).

The contract may be terminated if it met the following assumptions:

a) the contract to be two-sided contract;

b) the other party does not perform its obligation;

c) the requirement of notice.

\subsection{Termination when performing within the specified period of time is a basic term of a contract}

The main rule is contained in Article 114 according to which: "When the performance of an obligation within the specified period is a basic element of the contract, and the debtor will not perform within that period, the contract is terminated under the law. When the creditor asked for performance and the asked performance has not received within a reasonable time, he can declare the contract terminated. These rules apply in the case when the parties foresee that the contract will be deemed terminated if it's not performed within the specified period of time, and also when the performance of the contract within specified period is a basic term of contract according to the nature of the transaction."

With provisions of this Article shall be regulated termination of the fixed contracts. To be called a fixed contract based on a specified period for performance, it is necessary the period of time to be fixed (strict). In other words, the period of time should be explicitly agreed by the parties as a basic term of the contract or the importance comes from the nature or from the purpose of the contract (Галев, Дабовиќ-Анастасовска, 2009). From the contract may result that the specified period of time presents a basic term of the contract if it contains clauses such as "fixed", "in a strict time", "no later than...", etc. According to the nature of the transaction, the period of time is considered to be specified when, for example, are ordered Christmas trees to celebrate the New Year or Christmas, and these trees weren't delivered by that date (Чавдар, 2001). 


\subsection{Termination when performing within the specified period of time is not a basic term of a contract}

When the performance of the obligation in fixed period of time is not a basic term of the contract and if the creditor wants to terminate the contract, then he must fix an additional period of time for performance (Article 115(2)(3) of the Law on Obligations). On the other hand, if the debtor does not perform his obligations within the additional period of time fixed by the creditor, into consideration come the same consequences as in the case as where the period of time is an basic term of the contract. Non-fixed-term contracts are those where their performance by the debtor may be followed after his delay. The logic of this possibility lies in the justification of the debtor that the delayed performance does not violate the immediate interests of the creditor therefore it is more feasible to allow the performance of the contract and to ask for damages from the delay, than to terminate the contract and to ask for damages due to failure (Галев, ДабовиќАнастасовска, 2009).

If one of the parties fail to fulfill its souring obligation although it was not prevented by circumstances which exempts from responsibility, and was provided with additional time for performing its obligation, then it would be enough reason for the other party to terminate the contract (Чавдар, 2001).

\section{Conclusions}

The right to terminate regulated under the provisions of Macedonian Law and PECL is remedy of a specific character. It may also be defined as last resort remedy, due to the strict effects, which result from its exercise. The substantive grounds constituting the basic of their existence under two regulations are different. The fundamental character of the non-performance by either of the parties is the basic notion underlying the concept of termination under the provisions of PECL, while under Macedonian Law the period of time in which the contract should be performed (regardless as a basic or not basic term of the contract) forms the primary ground for termination of the contract. Setting the notion of fundamental non-performance and defining it, PECL provides a clear approach to contracting parties, ensuring them about the possibility of exercising the remedy of termination. Lack of fundamental non-performance can be considered as an apparent lack of the Macedonian Law. PECL, as well as the Macedonian Law, lays down the possibility of setting an additional period of time by the aggrieved party and awaiting the performance to be rendered. If the debtor doesn't perform its contract obligation during that additional period, the aggrieved party may terminate the contract at the end of the additional period of time. This second ground for termination of the contract is very similar in both regulations.

\section{References}

Bianca, C. \& Michael Bonell. (1987). Commentary on the Internacional Sales Law. Milan: Giuffrè, 1987.

Kröll, S. \& Loukas Mistelis \& Pilar Perales Viscasillas (2011). UN Convention on Contracts for the International Sale of Goods (CISG): Commentary, München: Verlag C.H. Beck.

Lando, O., \& Hugh Beale. (2000). Principles of European Contract Law, Parts I and II. Hague, London, Boston: Kluwer Law International.

Law on Obligations, Official Gazette of the Republic of Macedonia. No. 18/2001; amended by the Law Amending the Law on Obligations, Official Gazette No.4/2002; No.5/2003; No.84/2008; No.81/2009; No.161/2009; The decision of the Constitutional Court No.121/2001, and No.67/2002.

Magnus, U. (2006). "The Remedy of Avoidance of Contract Under CISG - General Remarks and Special Cases". 25 Journal of Law and Commerce (2005-06) (pp. 423-436).

Schlechtriem, P. \& Ingeborg Schwenzer (2005). Commentary on the UN Convention on the International Sale of Goods (CISG), second (english) edition, New York: Oxford University Press.

Schwenzer, I. (2010). "The Right to Avoid the Contract", Uniform Sales Law Conference - The CISG at its 30th Anniversary (A Conference in Memory of Albert H. Kritzer), (pp.225-230). University of Belgrade: Faculty of Law.

Schwenzer, I. \& Pascal Hachem \& Christopher Kee (2012). Global sales and contract law, Oxford: Oxford University Press.

Галев, Г., \& Јадранка Дабовиќ-Анастасовска (2009). Облигационо право. Скопје: Центар за европско применето право и економија (цеппе).

Чавдар, К. (2001). Закон за облигационите односи: коментари, објаснувања, практика и предметен регистар, Скопје: Агенција „АКАДЕМИК“. 